\title{
Variation of lignite ash \\ in vertical and horizontal sections of mining walls in the Konin Lignite Mine, central Poland
}

\author{
Lilianna Chomiak \\ Adam Mickiewicz University in Poznań, Institute of Geology; ul. B. Krygowskiego 12, 61-680 Poznań, Poland; \\ e-mail: lilcho@amu.edu.pl; ORCIDID:0000-0003-4932-2732
} (C) 2020 Author. This is an open access publication, which can be used, distributed and reproduced in any medium according
to the Creative Commons CC-BY 4.0 License requiring that the original work has been properly cited.

Received: 16 January 2020; accepted: 3 April 2020; first published online: 18 April 2020

\begin{abstract}
This paper focuses on the variations of lignite ash along selected sections and mining walls from three lignite opencast mines in central Poland. They are owned by the Konin Lignite Mine, where the first Mid-Polish lignite seam is being mined to produce electricity. Ash content in lignite is important because ash lowers the calorific value of the lignite. The results obtained are based on 266 samples of lignite collected from the Drzewce, Tomisławice, and Jóźwin IIB opencasts. All samples were tested according to ISO 1171 standard procedures, that is, they were first burned at a temperature of $850^{\circ} \mathrm{C}$, then the ash content was determined on a dry basis $\left(A^{d}\right)$, before the basic statistical parameters were calculated. The studied lignite seam is characterised by a variable distribution pattern of ash both along selected vertical sections and lignite walls, as well as between the three opencasts. The ash content of individual samples ranged from 6.5 to $69.8 \mathrm{wt} \%$, while the average content in opencast mines varied from 9.7 to $17.6 \mathrm{wt} \%$. The coefficient of variation is large (80.23-96.33\%) in the case of the Drzewce and Tomisławice, and low to average (14.53-37.75\%) in the case of Jóźwin IIB. Significant ash enrichment of some beds is interpreted in this article as a consequence of floods occurring in a Mid-Miocene mire (backswamp), but also of chemical precipitation. When lignite is burned to generate electricity, a relatively large amount of ash is produced. Therefore, recognition of ash content in lignite, in addition to the chemical composition and phase of ash, is recommended to better protect the environment. At the first stage of protection, it can be best achieved by analysing field samples for ash content.
\end{abstract}

Keywords: Middle Miocene, backswamp, inorganic matter, coefficient of variation

\section{INTRODUCTION}

Approximately $30-35 \%$ of the electricity in Poland is generated from lignite (Tajduś et al. 2014, Polskie Sieci Elektroenergetyczne 2019). This is the second-most abundant raw material, after bituminous coal (hard coal), used in the Polish energy mix; about $20 \%$ of electricity is produced from renewable energy sources: solar, hydro, geothermal, wind, and biomass (Tajduś et al. 2014, Widera et al. 2016). Therefore, the composition of lignite, its ash content, as well as chemical and phase composition, is important during mining and combustion activities.

Parameters such as organic matter, water content and ash content affect fuel quality. The values of these parameters are especially useful in evaluating the suitability of lignite for combustion in lignite-fired power plants (e.g. Kozula \& Mazurek 1996, Kwiecińska \& Wagner 1997, Kozula 2001, Naworyta 2008, Naworyta \& Mazurek 2010, Mastej et al. 2015, Pawelec \& Bielowicz 2016). According to Polish norms, the ash content in lignite must be lower than $40 \mathrm{wt} \%$, on a dry basis (Rozporządzenie 2001). 


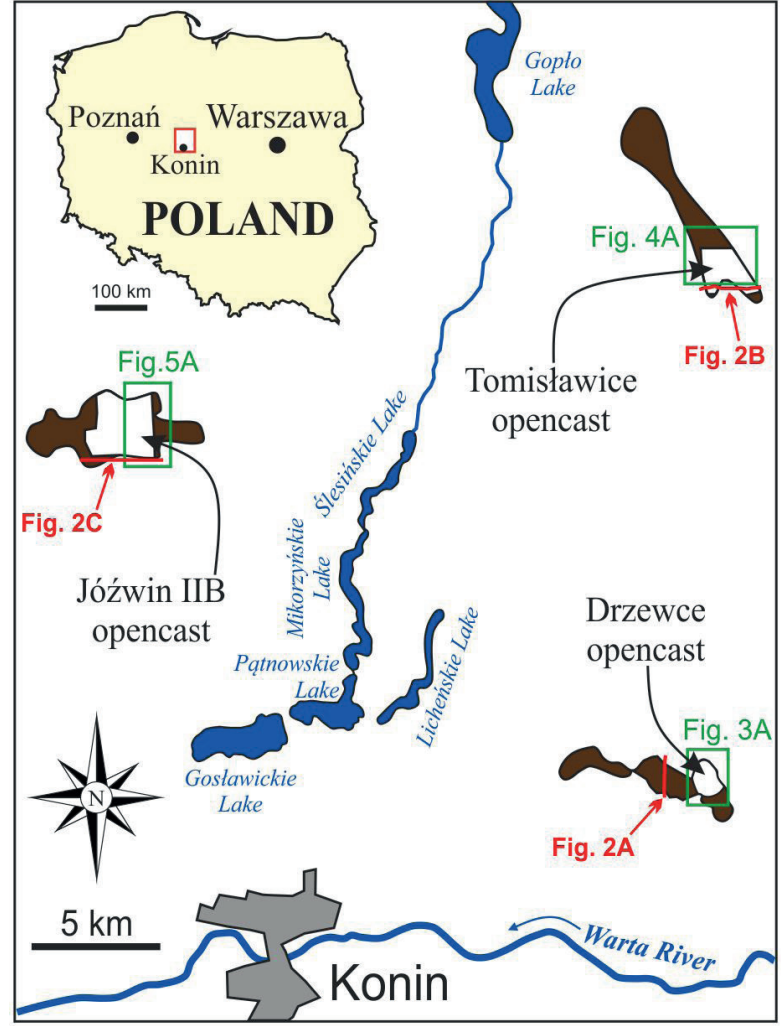

Fig. 1. Location map of the lignite opencast mines currently operating in the vicinity of Konin, central Poland

In the context of this study, the research question arose as to how the ash content in the lignite seam changes spatially. Hence, the main goals of the current study are (1) to present the quantitative ash content in the first Mid-Polish lignite seam from Drzewce, Tomisławice, and Jóźwin IIB opencasts (Fig. 1), which belong to the Konin Lignite Mine, (2) to calculate and compare basic statistical parameters for the ash content results obtained, and (3) to briefly discuss the impact of ash on the combustion of lignite and its environmental ramifications.

\section{GEOLOGICAL BACKGROUND}

Geologically, the research area is situated in the Szczecin-Miechów Synclinorium in the eastern part of the Mogilno-Łódź Segment (Żelaźniewicz et al. 2011). According to an older division of Poland into tectonic units, this region is located in the central part of the Mogilno-Łódź Basin, above the south-eastern slope of a deeply-rooted salt structure called the Gopło Anticline (Dadlez et al. 2000). The lignite deposits fill graben-like tectonic depressions that are up to several dozen metres deep. These grabens began to develop at the turn of the Eocene/Oligocene or the Oligocene/Miocene transition as evidenced by the age of these deposits (Fig. 2, Widera \& Kita 2007, Widera 2014).

The oldest sediments drilled in each of the three lignite deposits studied are predominantly marls of Late Cretaceous age (Fig. 2, Dadlez et al. 2000, Widera 2007). In the case of the Drzewce and Tomisławice opencasts, Paleogene glauconitic sands, with their characteristic greenish colour, lie on top of Mesozoic bedrock (Fig. 2A, B). These glauconitic sands are obviously of marine origin (Widera \& Kita 2007). In the Jóźwin IIB opencast, sediments of Paleogene age were not documented until the end of 2019 (Fig. 2C).

Neogene deposition started after a period of uplift and erosion during the Late Oligocene, when the area that is now central Poland began to undergo subsidence. During this time, mainly fluvial sedimentation occurred in this area. The Neogene succession began with the deposition of sand approximately $10-40 \mathrm{~m}$ thick, often containing organic matter. These deposits belong to the Koźmin Formation of Early to Mid-Miocene age (Fig. 2).

The Poznan Formation of Mid-Miocene to earliest Pliocene age ends the Neogene succession in the study area. This formation is divided into two lithostratigraphic members: the older Grey Clays Member and the younger Wielkopolska Member (Fig. 2, Piwocki \& Ziembińska-Tworzydło 1997). The first Mid-Polish lignite seam belongs to the Grey Clays Member of Mid-Miocene age (Piwocki \& Ziembińska-Tworzydło 1997, Kasiński \& Słodkowska 2016). The thickness of this lignite seam reaches up to $19.8 \mathrm{~m}$, but is less than $10 \mathrm{~m}$ on average (Fig. 2, Piwocki 1992, Widera 2007, 2014, Bechtel et al. 2019).

The Wielkopolska Member is the youngest lithostratigraphic unit in central Poland and is of late Mid-Miocene to earliest Pliocene age (Piwocki \& Ziembińska-Tworzydło 1997). It consists predominantly of overbank muds ( $>95$ vol.\%) and channel-fill sands and muds ( $<5$ vol.\%). In the study area, these deposits are up to $30 \mathrm{~m}$ thick with evidence of glaciotectonic disturbances (Fig. 2). In recent years, the origin of this member has been connected with the environment of an upper Neogene anastomosing river system (e.g. Maciaszek et al. 2019, Widera et al. 2019). 

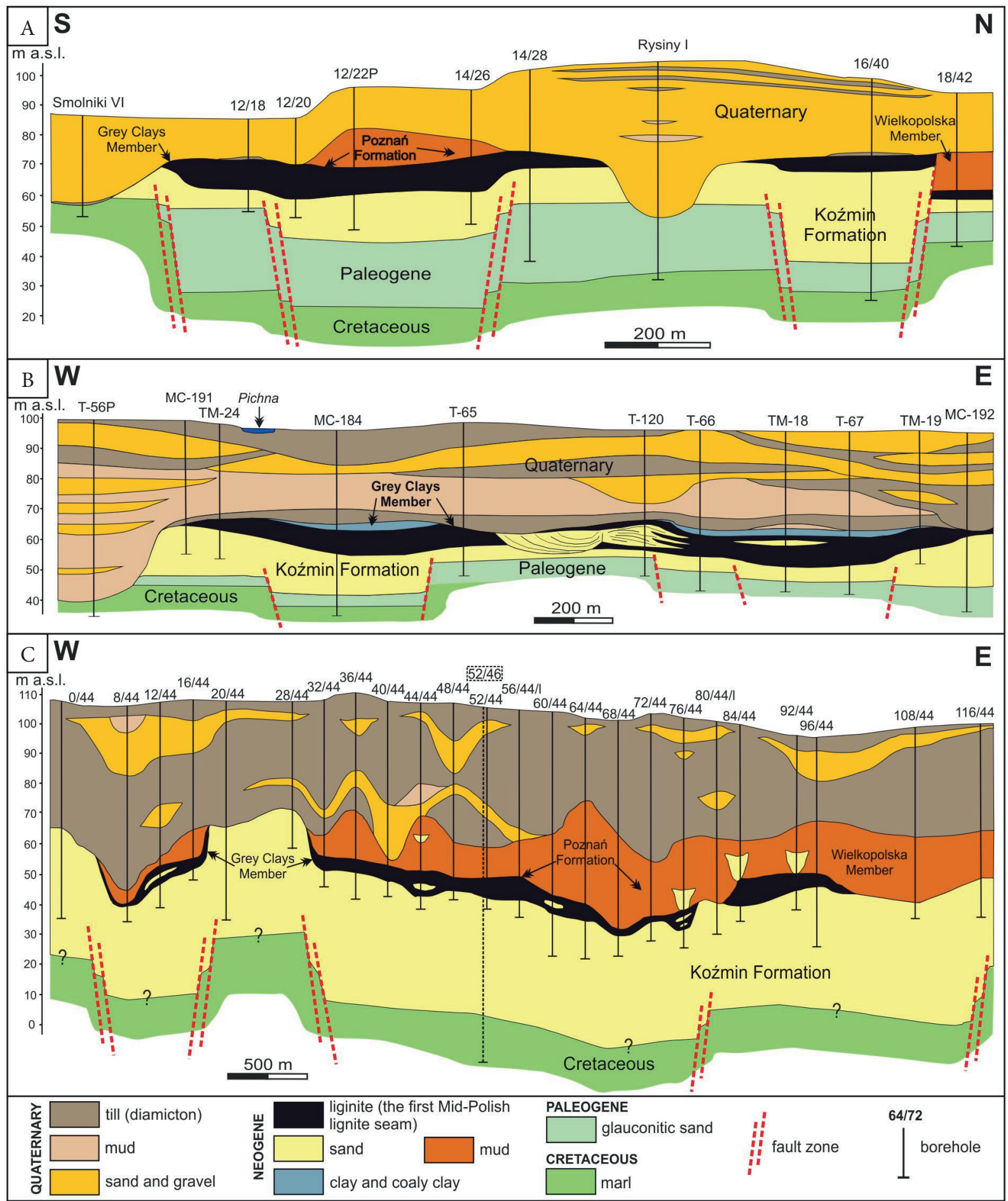

Fig. 2. Geological cross-sections through the studied lignite deposits: A) Drzewce with Drzewce opencast (after Widera 2007, modified); B) Tomisławice with Tomisławice opencast (after Widera et al. 2017, modified); C) Pątnów IV with Jóźwin IIB opencast (after Widera 2014, modified); for the location of cross-sectional lines, see Figure 1

The Neogene succession is covered by Quaternary sediments such as glacial tills, fluvioglacial gravels and sands, and glaciolacustrine muds. These deposits were strongly eroded and deformed by the Scandinavian ice sheets and/or their melt waters. Therefore, the Quaternary thickness varies between 20 and $60 \mathrm{~m}$ of overburden on the first Mid-Polish lignite seam (Fig. 2). 


\section{MATERIALS AND METHODS}

\section{Fieldwork}

Fieldwork was conducted in 2018-2019 at three operational opencasts belonging to the Konin Lignite Mine. A total of 266 samples of lignite were collected from three different lignite deposits and opencasts: "Drzewce" lignite deposit in the Drzewce opencast, "Tomisławice" lignite deposit in the Tomisławice opencast, and "Pątnów IV" lignite deposit in the Jóźwin IIB opencast (Fig. 1). The first Mid-Polish lignite seam was sampled in each of these opencasts along the vertical sections and walls exploited (Figs. 3-5).

In the case of the vertical sections, 33-36 samples were collected at an interval of $10-20 \mathrm{~cm}$. On the other hand, samples taken along the lignite walls were collected at intervals of $1 \mathrm{~m}$ or more. The profiles were separated from each other by approximately $200 \mathrm{~m}$. The obtained results are presented in graphical form in Figures 3-8.

\section{Laboratory analysis}

All analyses of the ash content were made in accordance with the applicable ISO 1171:2010 standard and Polish equivalent PN-ISO 1171:2002 standard. They were conducted at the laboratory of the Institute of Geology in Poznań. Results from laboratory tests were subjected to basic statistical analysis using Microsoft Excel. Several statistical parameters (mean, minimum, maximum values, and coefficients of variation) were calculated (Tabs. 1, 2), similar to the studies devoted to other Polish lignite deposits (e.g. Kasiński 1986, Naworyta \& Mazurek 2010, Bielowicz 2013, Naworyta \& Wasilewska-Błaszczyk 2014). In the case of ranges of the coefficient of variation, the classification according to Mucha (1994) was used.
Moreover, four histograms were prepared in order to sum up the distribution of the ash content results obtained. It was assumed that the sizes of the bins (intervals) were $5 \mathrm{wt} \%$ (Fig. 9).

\section{RESULTS}

\section{Drzewce opencast}

Ninety-one samples of lignite were collected from the Drzewce opencast, including 36 samples from the selected section $\mathrm{D}$, and 55 from the exploitation fronts. The sampled lignite walls (sections) were 4.5-12.2 m high (Fig. 3). All these lignite samples were analysed for ash content.

In the case of section $\mathrm{D}$, the arithmetic average ash content was $12.6 \mathrm{wt} \%$, on a dry basis. However, it varies across a wide range from 6.7 to $66.0 \mathrm{wt} \%$ (Fig. 3B, Tab. 1). The highest values of ash content exceeded $30.0 \mathrm{wt} \%$ and were obtained from the lowermost beds of the lignite seam. The upper parts of this seam were characterised by a very even and relatively low ash content $(<10 \mathrm{wt} \%)$, in which only 3 samples contained between 10.0 and $14.0 \mathrm{wt} \%$ (Fig. 3B). The coefficient of variation for these 36 samples was equal to $96.33 \%$ (Tab. 1).

The arithmetic average ash content along the lignite walls was $15.0 \mathrm{wt} \%$, ranging from 6.5 to 69.8 wt\% (Figs. 3C, 4, Tab. 2). Samples located close to the floor or roof of the seam had the highest ash content, exceeding 20-30 wt\%. Similarly, sample number 52 , situated in the middle part of the seam, was characterised by an ash content higher than $30 \mathrm{wt} \%$. The remaining majority of the analysed lignite samples had an ash content below or slightly above $10.0 \mathrm{wt} \%$ (Fig. 4). Finally, in the case of these 55 samples, the coefficient of variation was $80.23 \%$ (Tab. 2).

Table 1

Basic statistical parameters of ash content obtained for selected sections of the first Mid-Polish lignite seam from opencasts of the Konin Lignite Mine

\begin{tabular}{|l|c|c|c|c|c|}
\hline $\begin{array}{c}\text { Name } \\
\text { of opencast mine }\end{array}$ & $\begin{array}{c}\text { Average ash } \\
\text { content }\left(\boldsymbol{A}^{d}\right) \\
{[\mathbf{w t} \%]}\end{array}$ & $\begin{array}{c}\text { Maximum ash } \\
\text { content }\left(\boldsymbol{A}^{d}\right) \\
{[\mathbf{w t} \%]}\end{array}$ & $\begin{array}{c}\text { Minimum ash } \\
\text { content }\left(\boldsymbol{A}^{d}\right) \\
{[\mathbf{w t} \%]}\end{array}$ & $\begin{array}{c}\text { Standard } \\
\text { deviation }\end{array}$ & $\begin{array}{c}\text { Coefficient of } \\
\text { variation [\%] }\end{array}$ \\
\hline Drzewce & 12.6 & 66.0 & 6.7 & 12.09 & 96.33 \\
\hline Tomisławice & 17.6 & 71.4 & 9.6 & 14.29 & 81.15 \\
\hline Jóźwin IIB & 9.7 & 13.7 & 7.4 & 1.41 & 14.53 \\
\hline
\end{tabular}




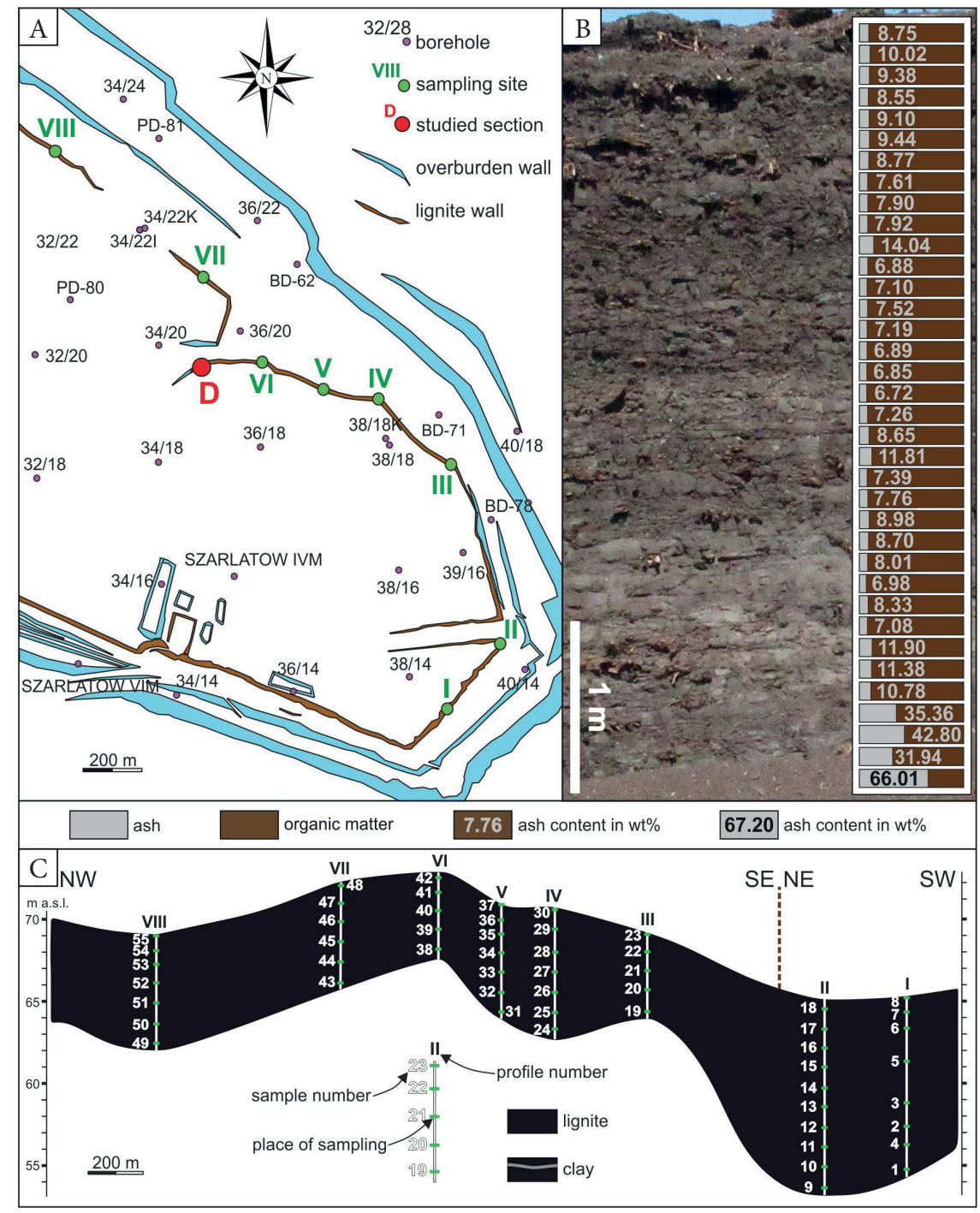

Fig. 3. Drzewce lignite opencast mine: A) location of the examined lignite walls with sampling sites I-VIII and the selected section $D ; B)$ broad view of the lignite seam with results of ash content tests; C) location of sampling sites along lignite walls; for the results of ash content tests see Figure 4

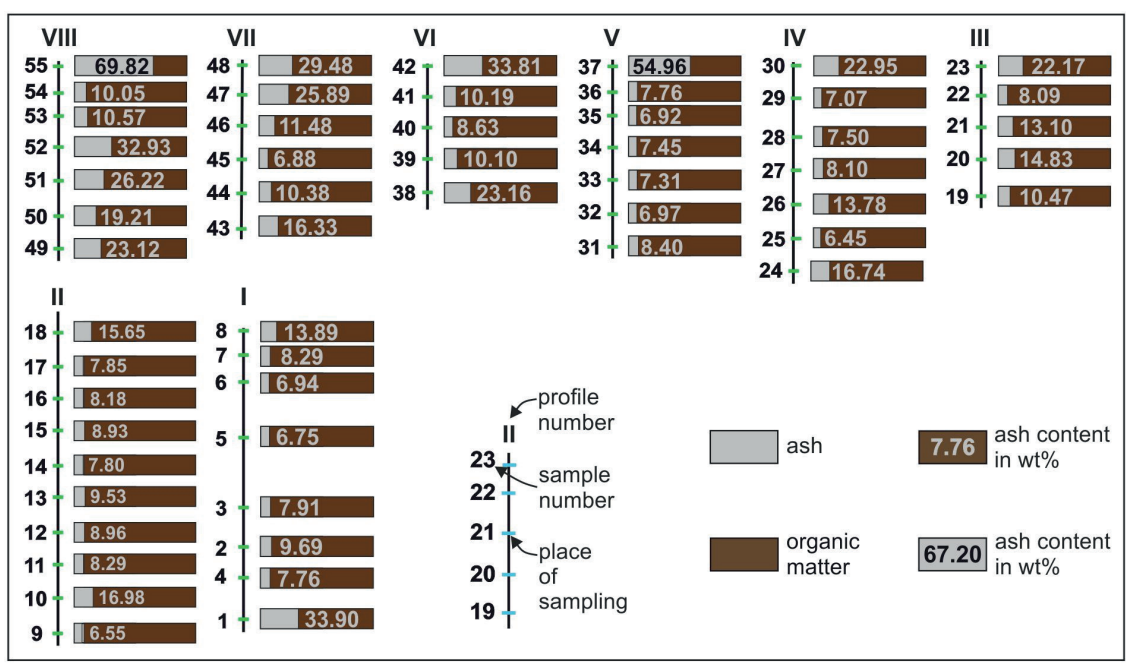

Fig. 4. Results of ash content tests obtained from lignite walls in the Drzewce opencast; for the location of sampling sites, see Figure $3 A$ and $C$ 


\section{Tomisławice opencast}

From the Tomisławice opencast, 87 samples of lignite were collected -36 from section $\mathrm{T}$ and 51 from the lignite walls (Fig. 5). At the sampling sites, the first Mid-Polish lignite seam was thick, ranging from 7.4 to more than $10 \mathrm{~m}$. The ash contents are shown graphically in Figures $5 \mathrm{~B}$ and 6 .

Section $\mathrm{T}$ contained $14.8 \mathrm{wt} \%$ (on a dry basis) of ash on average, but the variation in content was large, ranging from 6.9 to $71.4 \mathrm{wt} \%$ (Fig. 5B,
Tab. 1). Some samples contained an ash content $20-30 \mathrm{wt} \%$ higher in various parts of the lignite seam. These samples were found in floor, middle and roof layers of the seam, however, the most interesting two samples were situated about $1 \mathrm{~m}$ from the roof of the seam. These two samples contained an ash content of 69.8 and $71.4 \mathrm{wt} \%$. In the middle part of this section, only two samples contained less than $10 \mathrm{wt} \%$ ash (Fig. 5B). For all 36 samples from section $\mathrm{T}$, the coefficient of variation reached $81.15 \%$ (Tab. 1).

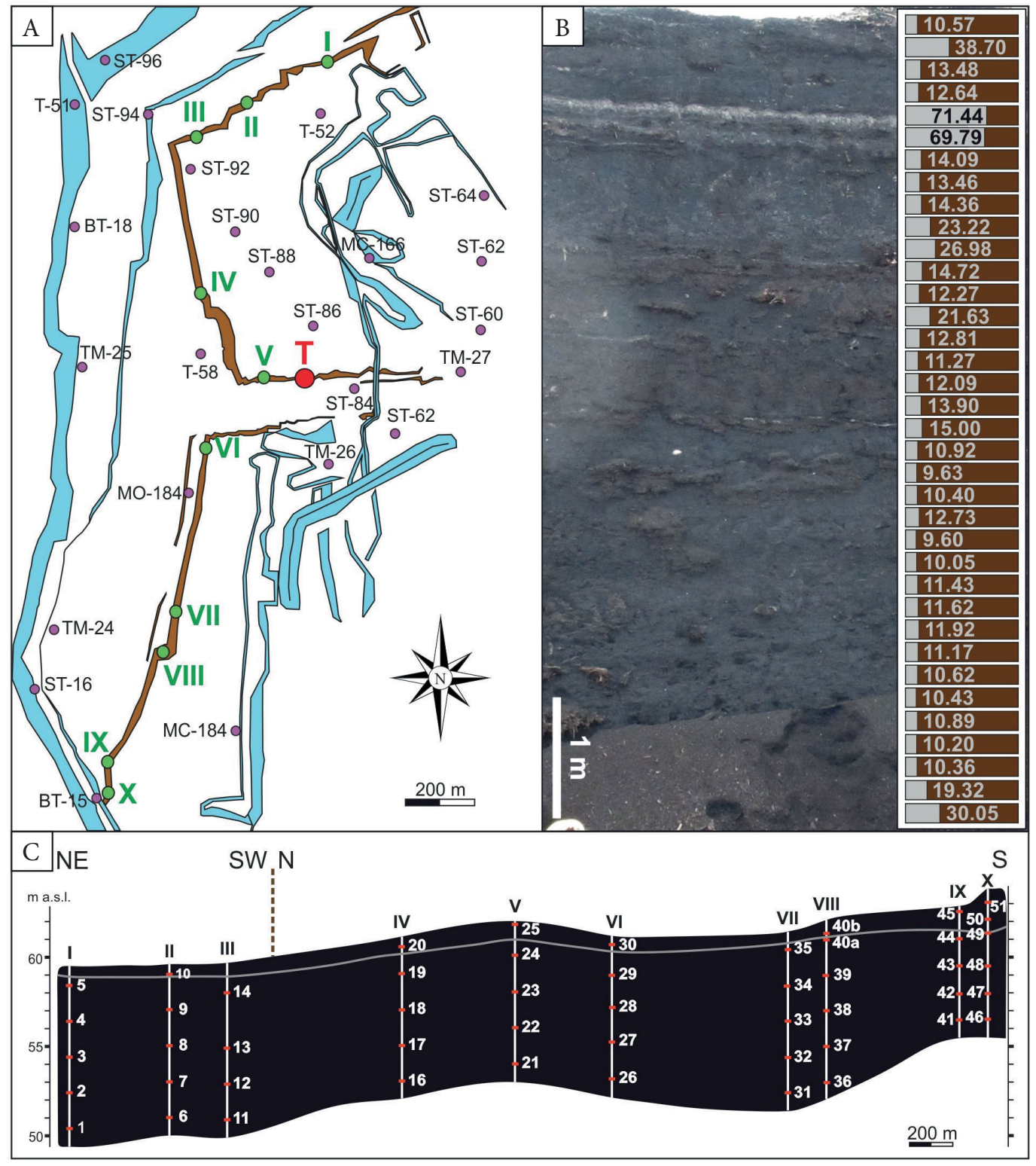

Fig. 5. Tomistawice lignite opencast mine: A) location of the examined lignite walls with sampling sites I-X and the selected section $T ; B$ ) broad view of the lignite seam with results of ash content tests; C) location of sampling sites along lignite walls; for the results of ash content tests see Figure 6; for explanations see Figure 3 


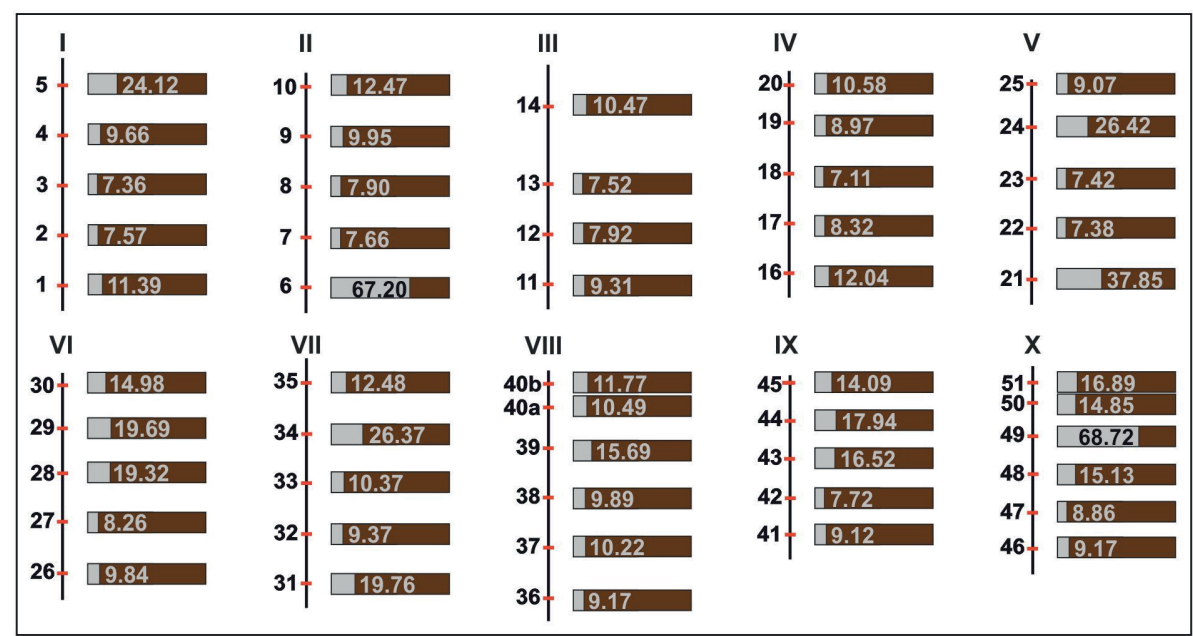

Fig. 6. Results of ash content tests obtained from lignite walls in the Tomisławice opencast; for location of sampling sites see Figure $5 A$ and $C$; for explanations see Figure 4

Table 2

Basic statistical parameters of ash content obtained for exploited lignite walls of the first Mid-Polish lignite seam from opencasts of the Konin Lignite Mine

\begin{tabular}{|l|c|c|c|c|c|}
\hline $\begin{array}{c}\text { Name of } \\
\text { opencast mine }\end{array}$ & $\begin{array}{c}\text { Average ash } \\
\text { content }\left(\boldsymbol{A}^{\boldsymbol{d}}\right) \\
{[\mathbf{w t} \%]}\end{array}$ & $\begin{array}{c}\text { Maximum ash } \\
\text { content }\left(\boldsymbol{A}^{\boldsymbol{d}}\right) \\
{[\mathbf{w t} \%]}\end{array}$ & $\begin{array}{c}\text { Minimum ash } \\
\text { content }\left(\boldsymbol{A}^{\boldsymbol{d}}\right) \\
{[\mathbf{w t} \mathbf{t}]}\end{array}$ & $\begin{array}{c}\text { Standard } \\
\text { deviation }\end{array}$ & $\begin{array}{c}\text { Coefficient of } \\
\text { variation [\%] }\end{array}$ \\
\hline Drzewce & 15.0 & 69.8 & 6.5 & 12.01 & 80.23 \\
\hline Tomisławice & 14.8 & 68.7 & 7.1 & 12.31 & 83.41 \\
\hline Jóźzin IIB & 13.9 & 30.5 & 7.8 & 5.23 & 37.75 \\
\hline
\end{tabular}

In the case of 51 samples collected along the lignite walls, the average value of the ash content was $14.8 \mathrm{wt} \%$ and ranged from 7.1 to $68.7 \mathrm{wt} \%$ (Figs. 5C, 6, Tab. 2). The vertical and horizontal distribution of the ash did not show any regularity. Some floor and roof samples were characterised by clearly higher ash content (24.1-67.2 wt\%), for example, samples 5, 6 and 24. Similarly, sample 49 contained very high ash content, reaching up to 68.7 wt\% (Fig. 6). The coefficient of variation for these all samples was equal to $83.41 \%$ (Tab. 2).

\section{Jóźwin IIB opencast}

Eighty-eight samples were collected from the Jóźwin IIB opencast and analysed for ash content. Thirty-three of the samples came from the 3-m high section J, while the remaining 55 samples were collected from the mine walls up to $8.5 \mathrm{~m}$ high (Figs. 7B, 8).
In the Jóźwin IIB opencast mine, the average arithmetic ash content of the first Mid-Polish lignite seam was $9.7 \mathrm{wt} \%$ for section J. In this case, the difference between the maximum (13.7 wt\%) and minimum (7.4 wt\%) ash content was only $6.3 \mathrm{wt} \%$ (Fig. 7B, Tab. 1). Excluding the two lowest samples from the floor of the lignite seam, the ash content and distribution along section J was relatively low and fairly even. For the majority of these samples, the ash content was in the range of $10 \pm 2 \mathrm{wt} \%$ (Fig. 7B). This is confirmed by the very low value of the coefficient of variation for $33 \mathrm{sam}$ ples, which was only $14.53 \%$ (Tab. 1).

On the other hand, the arithmetic average ash content along the lignite walls was $13.9 \mathrm{wt} \%$ and ranged from 7.8 to $30.5 \mathrm{wt} \%$ (Figs. $7 \mathrm{C}, 8$, Tab. 2). A few samples had ash contents greater than $20 \mathrm{wt} \%$, and a dozen or so samples contained less than $10 \mathrm{wt} \%$ ash. Thus, most of the 55 samples had an ash content in the range of $10-20 \%$, and the coefficient of variation is relatively low, only $37.75 \%$ (Tab. 2). 


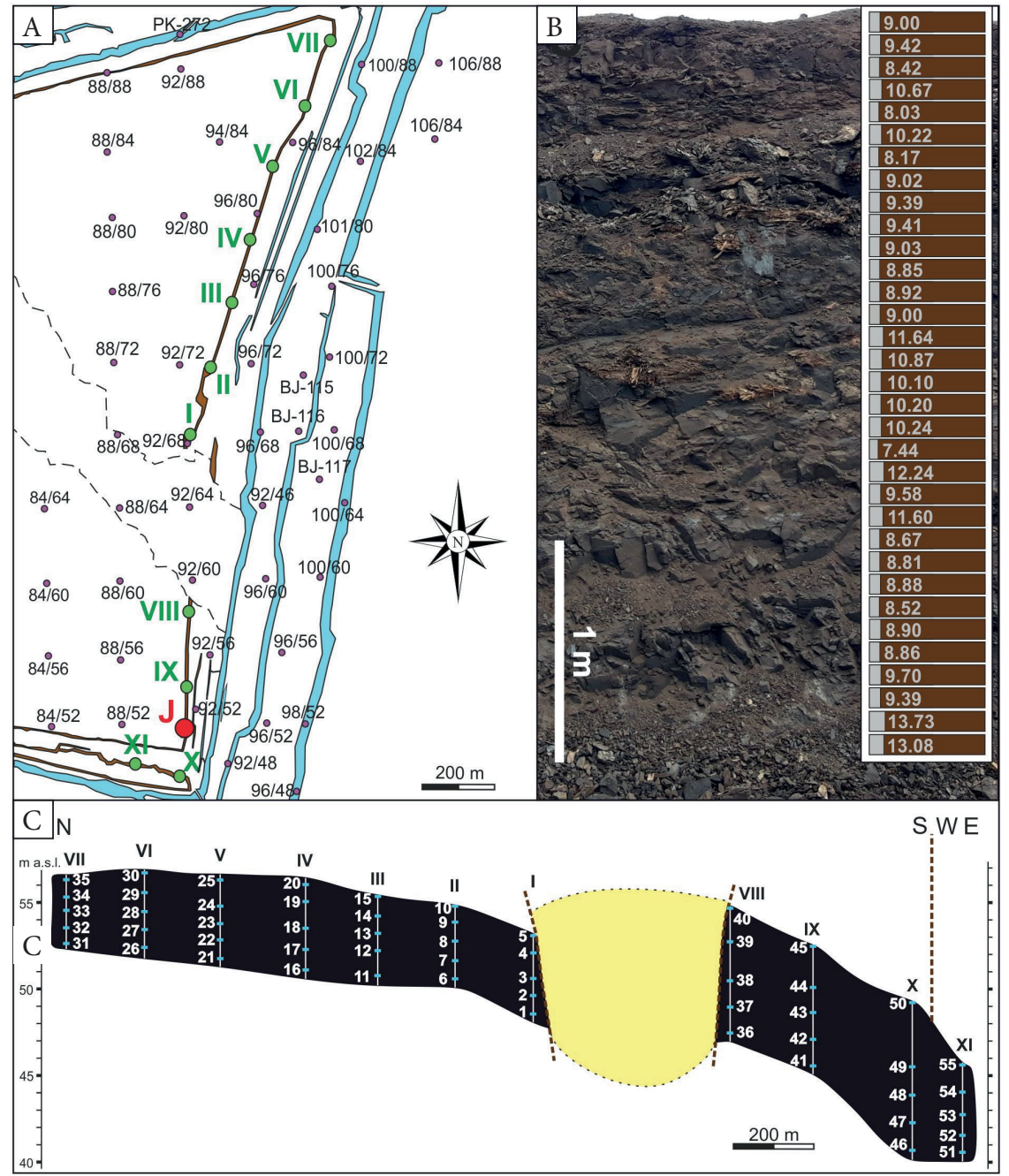

Fig. 7. Jóźwin IIB lignite opencast mine: A) location of the examined lignite walls with sampling sites I-XI and the selected section J; B) broad view of the lignite seam with results of ash content tests; C) location of sampling sites along lignite walls; for the results of ash content tests, see Figure 8; for explanations see Figure 3

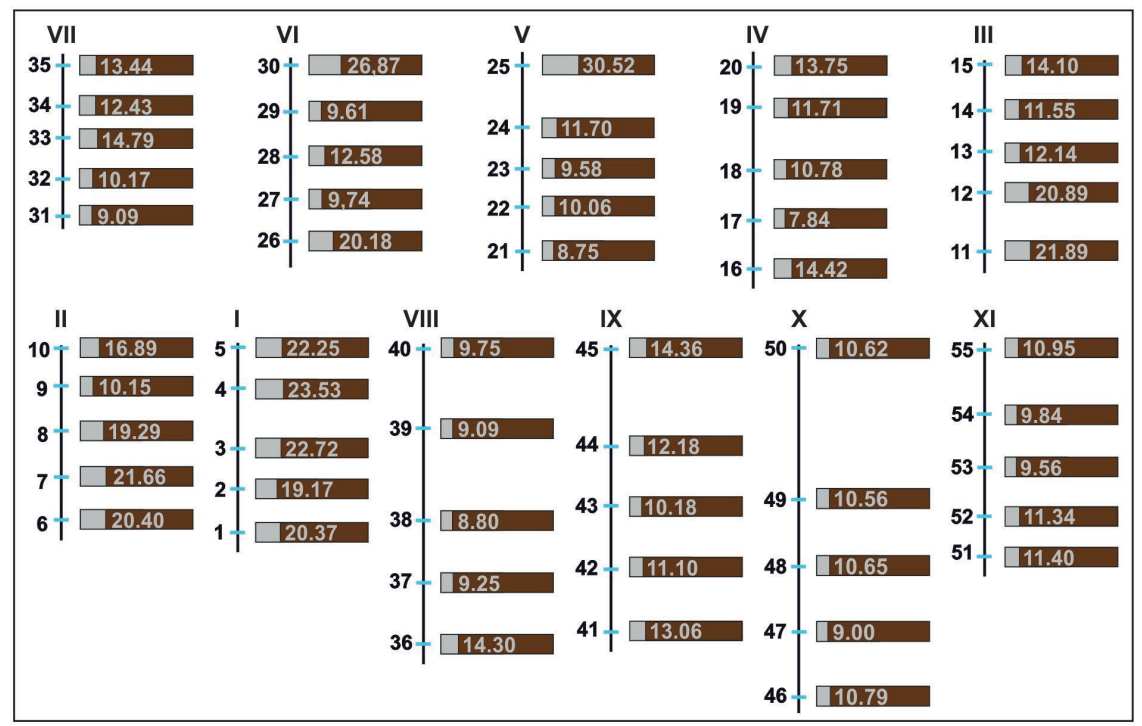

Fig. 8. Results of ash content tests obtained from lignite walls in the Jóźwin IIB opencast; for the location of sampling sites see Figure $7 A$ and C; for explanations see Figure 4 


\section{INTERPRETATION AND DISCUSSION}

The variation of ash content in the first Mid-Polish lignite seam, along vertical and horizontal sections of mining walls, will be briefly interpreted and discussed. Taking into account previous studies of this lignite seam, an initial attempt to clarify some issues can be made. Thus, ash content is a parameter that is given in both geological documentation (e.g. Kozula 2001) and scientific studies devoted to lignite deposits owned by the Konin Lignite Mine (e.g. Kozula \& Mazurek 1996, Naworyta 2008, Naworyta \& Mazurek 2010, Pawelec $\&$ Bielowicz 2016). In these contributions, various geostatistical methods, both standard and modern, were used as summarised by Mucha (1994) and Jurek et al. (2013). Regardless of the method applied, they all use the same data source that was obtained during exploration and documentation of the lignite deposits. Moreover, the ash distribution is most often shown in plan view, that is, on maps plotted by the appropriate computer program in recent years (e.g. Naworyta \& Mazurek 2010, Jurek et al. 2013, Mastej et al. 2015, Pawelec \& Bielowicz 2016). On the contrary, the methodology proposed in this paper additionally allows to present the ash content in the vertical section of the lignite seam to be determined (cf. Figs. 3-8). Therefore, the current research can be considered as complementary to those already mentioned.

Most likely, the increased ash content in some samples is at least partially attributable to the floods that occurred during the accumulation of peat (Middle Miocene), which in turn transformed into the first Mid-Polish lignite seam. This interpretation is supported by the fact that this lignite seam, especially in the Tomisławice and Jóźwin IIB opencasts, is often split by sandy and clayey partings. These interbeddings are likely connected with flood events during which siliciclastics were supplied to the mire (Widera 2016, Widera et al. 2017, Chomiak et al. 2019a, 2019b, 2020, Chomiak 2020). The effects of floods on mires (backswamps) located in close proximity to river channels are often described in the geological literature (e.g. Gradziński et al. 1976, Horne et al. 1978, Kasiński 1986, Smith et al. 1989, Zieliński 2014, and references therein). It should be noted that the relatively high content of $\mathrm{CaO}(\sim 30 \mathrm{wt} \%$ on average) in the ashes tested additionally indicates their autogenic origin.

In this paper, a macroscopically visible bed of siliciclastics within the exploited lignite seam was documented in the Tomisławice opencast mine. This $10-30 \mathrm{~cm}$ thick layer of clay in the upper part of the seam was found in two samples (Fig. 5B), and in sample 49 at sampling site $\mathrm{X}$ (Fig. 6). In fact, this layer comprises a coaly clay containing about $30 \mathrm{wt} \%$ organic matter and $70 \mathrm{wt} \%$ mineral matter (i.e. ash) (Fig. 5B). Because the siliciclastic partings are not the subject of the present study, their origin is not discussed here. However, the impact of the clayey bed on the ash content of the entire seam may be significant, as was found to be the case for the "Tomisławice" lignite deposit (Chomiak et al. 2020).

The distribution of ash content in the 266 lignite samples analysed from all currently operational opencasts belonging to the Konin Lignite Mine, is clearly visible on the histograms (Fig. 9). The shape of the statistical data is more similar in the case of lignite from the Tomisławice and Jóźwin IIB opencasts than from the Drzewce opencast. However, all these histograms are skewed right, that is, just like the histogram constructed for all samples (cf. Fig. 9A-D). This means that the largest number of lignite samples $(>78.5 \%)$ is characterised by ash content in the range of 5-10 and 10-15 wt\%, respectively. Consequently, only 8 samples analysed cannot be described as lignite because they contain $>40 \mathrm{wt} \%$ of ash (Fig. 9D, Rozporządzenie 2001).

On the other hand, the statistically-calculated ash content within the first Mid-Polish lignite seam provides some interesting conclusions (Tabs. 1, 2). The values of the coefficients of variation obtained clearly show the similarity between the lignite seams in the Drzewce and Tomisławice opencasts. According to Mucha's classification (1994), this is expressed as a large variation in ash content (41-100\%). In contrast to examples from the Drzewce and Tomisławice opencasts, the lignite seam from the Jóźwin IIB opencast is characterised by a low $(<20 \%$, in the case of section $\mathrm{J})$ to an average (21-40\%, in the case of the lignite walls) variation in ash content (Mucha 1994). At least two factors could have affected such significant 
differences in ash content and its coefficient of variation. Firstly, the investigated lignite seam from the Jóźwin IIB opencast has the smallest thickness and is the least internally differentiated (Fig. 7B, C). Secondly, the sampled part of the seam only covers its upper bench, which rests above the sandy partings representing crevasse-splay sediments (Chomiak et al. 2019a, 2019b).

Finally, the ash (mineral matter) has a negative impact on the environment due to the combustion of lignite in power plants, as well as during other methods of its utilization, such as gasification, carbonisation, and liquefaction (e.g. Shirazi et al. 1995, Gülen 2007, Naworyta 2008, Bielowicz 2013, and references therein). Therefore, the study of ash content in lignite seams is important, with many potential benefits for both industry and the environment. Detailed knowledge of the content and spatial distribution of ash in lignite deposits supplied to power plants can help reduce the amount of inorganic substance, and consequently less ash will be produced during combustion. This knowledge can help improve the quality of lignite used on an industrial scale, for example, by selective exploitation. Nevertheless, due to technological and financial limitations, this is practiced sporadically and only on a local scale by the Konin Lignite Mine (Chomiak et al. 2020).

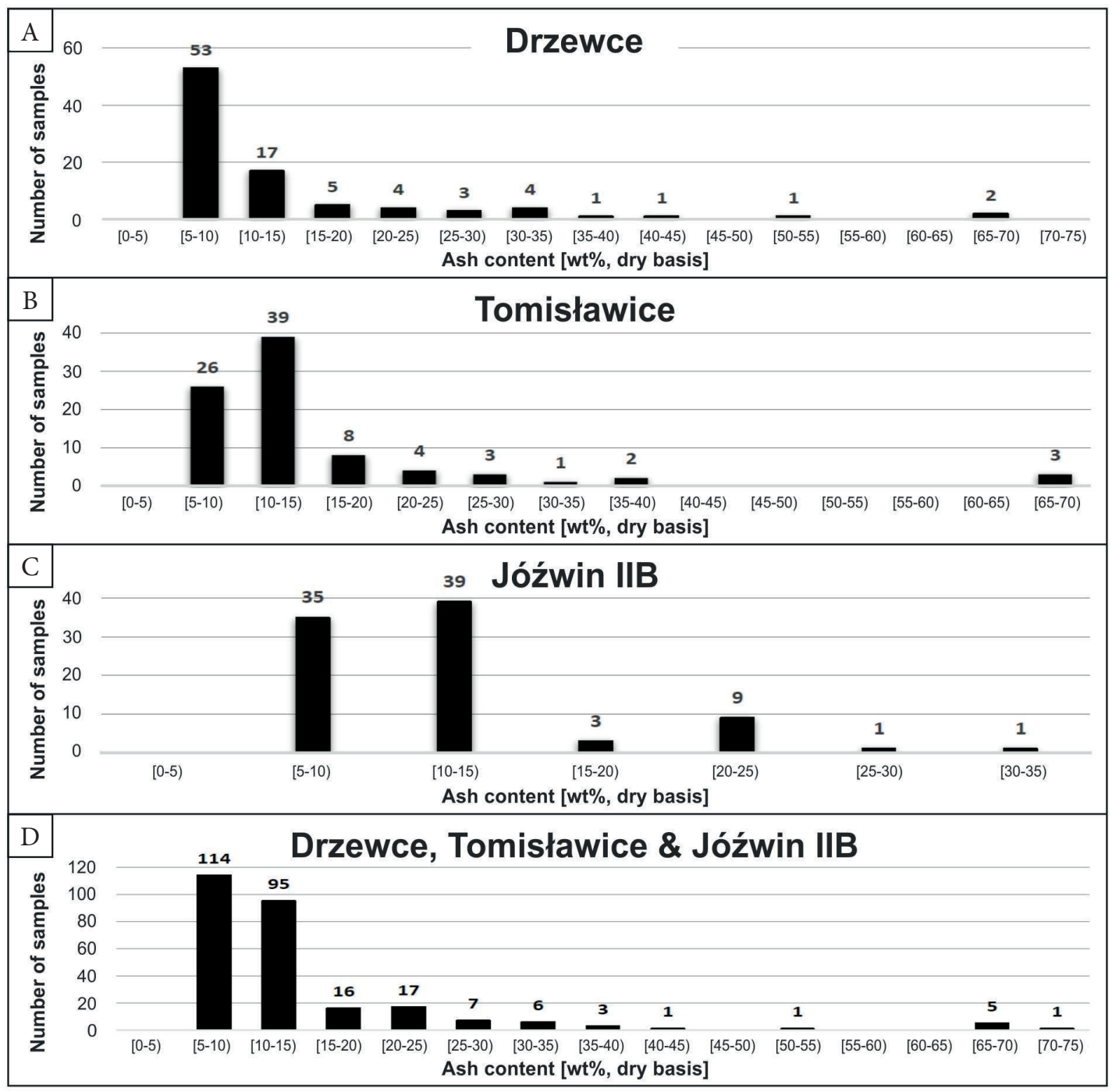

Fig. 9. Distribution of ash content in lignites from opencasts belonging to the Konin Lignite Mine: A) the Drzewce opencast; B) the Tomisławice opencast; C) the Jóźwin IIB opencast; D) all currently operating lignite opencasts; for detailed data see Figures 3-8 


\section{CONCLUSIONS}

The results presented in this study summarize almost two years of fieldwork and laboratory analyses, as well as answering the research question posed in the introduction. Thus, the following conclusions can be drawn:

1. The examined first Mid-Polish lignite seam is relatively thin ( $<10 \mathrm{~m}$ on average) and contains a lot of ash (>10 wt $\%$ on average). The spatial distribution of the ash is highly diverse and ranges from 6.5 to $69.8 \mathrm{wt} \%(9.7-17.6 \mathrm{wt} \%$ on average). However, over $78.5 \%$ of analysed lignite samples contain $5-15 \mathrm{wt} \%$ of ash.

2. The coefficients of variation calculated for the results obtained (80.23-96.33\%) indicate a large variation in ash content in lignites from the Drzewce and Tomisławice opencasts. The exceptions are lignites from the Jóźwin IIB opencast, where this coefficient is significantly lower (14.53-37.75\%).

3. Such large differences in ash content make some parts of the first Mid-Polish lignite seam unsuitable for the production of electricity. Therefore, better knowledge of this seam, through detailed ash content analysis, could contribute to environmental protection by selected exploitation (avoiding the ash-rich parts) of the lignite seam and related lower ash production. But is it possible in light of the adopted method of mining?

The author wishes to thank two anonymous reviewers and prof. dr. hab. Marian Wagner (AGH UST, Krakow) for their insightful remarks and comments that have improved the final version of this paper. Sławomir Kaczkowski, Krzysztof Komorowski and Ewa Orkowska (all from the Geological Department of the Konin Lignite Mine, Kleczew) are also thanked for their help during the fieldwork and archive studies, respectively. I would like to send additional words of gratitude to Mariusz Dziamara (the head of the Geological Department of the same mine) for his logistical support and Marek Widera (Institute of Geology, Poznań), supervisor of my PhD theses, for his encouragement and help in preparing the manuscript.
This paper was funded by the National Science Centre of Poland, research project no. 2017/27/B/ ST10/00001.

\section{REFERENCES}

Bechtel A., Widera M. \& Woszczyk M., 2019. Composition of lipids from the First Lusatian lignite seam of the Konin Basin (Poland): relationships with vegetation, climate and carbon cycling during the mid-Miocene Climatic Optimum. Organic Geochemistry, 138, 103908.

Bielowicz B., 2013. Charakterystyka odmian technologicznych węgla brunatnego do zgazowania naziemnego w reaktorze fluidalnym. Przegląd Górniczy, 69, 1-9.

Chomiak L., 2020. Architecture, sedimentology and depositional model for the formation of crevasse splays within a lignite seam at the Tomisławice opencast mine near Konin in central Poland. Geologos, 26, 25-37.

Chomiak L., Wachocki R., Maciaszek P., Widera M. \& Zieliński T., 2019a. Seismically deformed the crevasse-splay microdelta deposits - an example from Mid-Miocene of Poland. Geological Quarterly, 63, 162-177.

Chomiak L., Wachocki R., Maciaszek P., Widera M. \& Zieliński T., 2019b. Seismically-induced soft-sediment deformation in crevasse-splay microdelta deposits (Middle Miocene, central Poland) - reply. Geological Quarterly, 63, 429-433.

Chomiak L., Urbański P. \& Widera M., 2020. Architektura i geneza iłów w górnym poziomie węgli brunatnych formacji poznańskiej (środkowy miocen) - odkrywka Tomisławice koło Konina w środkowej Polsce. Przegląd Geologiczny, 69, accepted.

Dadlez R., Marek S. \& Pokorski J. (red.), 2000. Mapa Geologiczna Polski bez utworów kenozoiku w skali 1:1 000000. Państwowy Instytut Geologiczny, Warszawa.

Gradziński R., Kostecka A., Radomski A. \& Unrug R., 1976. Sedymentologia. Wydawnictwa Geologiczne, Warszawa.

Gülen J., 2007. Mineral Matter Identification in Nallıhan Lignite by Leaching with Mineral Acids. Energy Sources, Part A, 29, 231-237.

Horne J.C., Ferm J.C., Caruccio F.T. \& Baganz B.P., 1978. Depositional models in coal exploration and mine planning in Appalachian Region. American Association of Petroleum Geologist Bulletin, 62, 2379-2411.

ISO 1171:2010. Solid mineral fuels - Determination of ash.

Jurek J., Mucha J. \& Wasilewska-Błaszczyk M., 2013. Przegląd zastosowań geostatystyki do szacowania parametrów polskich złóż węgla brunatnego. Zeszyty Naukowe Instytutu Gospodarki Surowcami Mineralnymi i Energii Polskiej Akademii Nauk, 85, 143-153.

Kasiński J.R., 1986. Sedimentary models of small lignite deposits: examples from the Polish Neogene. Przegląd Geologiczny, 34, 189-197.

Kasiński J.R. \& Słodkowska B., 2016. Factors controlling Cenozoic anthracogenesis in the Polish Lowlands. Geological Quarterly, 60, 959-974.

Kozula R., 2001. Dokumentacja geologiczna złoża wegla brunatnego „Tomisławice” w kategorii B i C1 w Tomisławicach, Część I - tekst. Przedsiębiorstwo Geologiczne PROXIMA, Wrocław. 
Kozula R. \& Mazurek S., 1996. Wstępna ocena stopnia rozpoznania podstawowych parametrów złożowych konińskich złóż węgla brunatnego w blokach geologicznych metodą krigingu. Górnictwo Odkrywkowe, 38, 78-85.

Kwiecińska B. \& Wagner M., 1997. Typizacja cech jakościowych węgla brunatnego $z$ krajowych złóż według kryteriów petrograficznych i chemiczno-technologicznych dla celów dokumentacji geologicznej złóż oraz obsługi kopalń. Wydawnictwo Centrum PPGSMiE Polskiej Akademii Nauk, Kraków.

Maciaszek P., Chomiak L., Wachocki R. \& Widera M., 2019. The interpretive significance of ripple-derived sedimentary structures within the late Neogene fluvial succession, central Poland. Geologos, 25, 1-13.

Mastej W., Bartuś T. \& Rydlewski., 2015. Analysis of lithofacies cyclicity in the Miocene Coal Complex of the Bełchatów lignite deposit, south-central Poland. Geologos, 21, 285-302.

Mucha J., 1994. Metody geostatystyczne w dokumentowaniu $z \nmid o ́ z ̇$. Wydawnictwa AGH, Kraków.

Naworyta W., 2008. Analiza zmienności parametrów złożowych węgla brunatnego pod kątem sterowania jakością strumienia urobku. Gospodarka Surowcami Mineralny$m i, 24,97-110$.

Naworyta W. \& Mazurek S., 2010. Zastosowanie parametru cenowego jako wstęp do projektowania zagospodarowania górniczego złóż węgla brunatnego. Polityka Energetyczna, 13, 341-353.

Naworyta W. \& Wasilewska-Błaszczyk M., 2014. Analiza parametrów złoża węgla brunatnego dla potrzeb projektowania elektrowni. Polityka Energetyczna - Energy Policy Journal, 17, 127-136.

Pawelec S. \& Bielowicz B., 2016. Pozycja węgla brunatnego ze złoża Dęby Szlacheckie w klasyfikacjach międzynarodowych. Biuletyn Państwowego Instytutu Geologicznego, 466, 233-244.

Piwocki M., 1992. Zasięg i korelacja głównych grup trzeciorzędowych pokładów węgla brunatnego na platformowym obszarze Polski. Przegląd Geologiczny, 40, 281-286.

Piwocki M. \& Ziembińska-Tworzydło M., 1997. Neogene of the Polish Lowlands - lithostratigraphy and pollen-spore zones. Geological Quarterly, 41, 21-40.

Polskie Sieci Elektroenergetyczne, 2019. Produkcja i zużycie energii elektrycznej w elektrowniach krajowych. [in:] Raport 2018 KSE. Zestawienie danych ilościowych dotyczących funkcjonowania KSE w 2018 roku, PSE, 29-31.
PN-ISO 1171:2002. Paliwa stałe. Oznaczanie popiołu.

Rozporządzenie, 2001. Rozporządzenie Ministra Środowiska $z$ dnia 18 grudnia 2001 r. w sprawie kryteriów bilansowości złóż kopalin. Dz.U. 2001 nr 153, poz. 1774.

Shirazi A.R., Börtin O., Eklund L. \& Lindquist O., 1995. The impact of mineral matter in coal on its combustion. A new approach to the determination of the calorific value of coal. Fuel, 74, 247-251.

Smith N.D., Cross T.A., Dufficy J.P. \& Clough S.R., 1989. Anatomy of an avulsion. Sedimentology, 36, 1-23.

Tajduś A., Kaczorowski J., Kasztelewicz Z., Czaja P., Cała M., Bryja Z. \& Żuk S., 2014. Wegiel brunatny - oferta dla polskiej energetyki. Możliwości rozwoju działalności górnictwa wegla brunatnego w Polsce do 2050 roku. Komitet Górnictwa Polskiej Akademii Nauk, Kraków.

Widera M., 2007. Litostratygrafia i paleotektonika kenozoiku podplejstoceńskiego Wielkopolski. Seria Geologia, 18, Wydawnictwo Naukowe Uniwersytetu im. Adama Mickiewicza, Poznań.

Widera M., 2014. Lignite cleat studies from the first Middle-Polish (first Lusatian) lignite seam in central Poland. International Journal of Coal Geology, 131, 227-238.

Widera M., 2016. Depositional environments of overbank sedimentation in the lignite-bearing Grey Clays Member: New evidence from Middle Miocene deposits of central Poland. Sedimentary Geology, 335, 150-165.

Widera M., Kasztelewicz Z. \& Ptak M., 2016. Lignite mining and electricity generation in Poland: The current state and future prospects. Energy Policy, 92, 151-157.

Widera M. \& Kita A., 2007. Paleogene marginal marine sedimentation in central-western Poland. Geological Quarterly, 51, 79-90.

Widera M., Chomiak L., Gradecki D. \& Wachocki R., 2017. Osady glifu krewasowego z miocenu Polski środkowej w okolicach Konina. Przeglad Geologiczny, 65, 251-258.

Widera M., Chomiak L. \& Zieliński T., 2019. Sedimentary facies, processes and paleochannel pattern of an anastomosing river system: an example from the Upper Neogene of Central Poland. Journal of Sedimentary Research, 89, 487-507.

Zieliński T., 2014. Sedymentologia. Osady rzek i jezior. Wydawnictwo Naukowe Uniwersytetu im. Adama Mickiewicza, Poznań.

Żelaźniewicz A., Aleksandrowski P., Buła Z., Karnkowski P.H., Konon A., Ślączka A., Żaba J. \& Żytko K., 2011. Regionalizacja tektoniczna Polski. Komitet Nauk Geologicznych Polskiej Akademii Nauk, Wrocław. 